\title{
Conducting the Task-based Approach With Context Aware Mobile Situated Learning on Learning English for College Students’ Learning Performance*
}

\author{
Ju-yin Yang \\ Kainan University, Taoyuan City, Taiwan
}

\begin{abstract}
Learning English with specific purpose (ESP) initiatives domain knowledge and language ability with English learning to meet future job demands (Leroux \& Lafleur, 1995; Khan \& Khan, 2015). In the information age, the innovative technologies of mobile devices make the dramatical changes in ways of teaching and learning (Atkinson, 2011; Bierstaker, Janvrin \& Lowe, 2014, Pittaway, 2012; Yang \& Che, 2015). The focus of this study aims to examine ESP college students' English learning performance by using Context Aware Mobile Situated Learning (CAMSL) in Tourism and Hospitality Management field and other majors. The mixed research method is conducted for data collection and analysis. The quantitative data are collected by examining students' learning performance; the qualitative data are allowed to understand the students' perspective toward their role in using the CAMSL with Tourism related content. Eight-three students are randomly selected and divided into two groups: 42 students are assigned in the experimental group A (CAMSL), and 41 students are assigned in control group. Two groups of students receive pretest and posttest to examine their English performance. Besides, twenty students from group A and B are selected for online survey. The survey is mailed directly to students' email account. Results represented by using CAMSL show the significant improvement on students' learning performance. In addition, the survey data indicate the benefits of using the CAMSL help students enhance their academic discourse, develop their learned knowledge to represent their profession, use English properly to speak themselves up, and provide the effectiveness of obtain domain knowledge in future workplace.
\end{abstract}

Keywords: context aware mobile situated learning, mobile assisted language learning, college students

\section{Introduction}

English learning in higher education is facing crucial problems, particularly, motivation to engage in class, language performance to improve (Antonio \& Tuffley, 2015) and the way of making learning more effectiveness (O’Flaherty \& Phillips, 2015). Nowadays, the higher education aims to meet expectations for current college students, particular the needs of whole society and market industry. For instance, schools should develop learners' domain knowledge which emphasize on their specialized majors, increase the learners' competency,

\footnotetext{
* Acknowledgements: This research has been funded by Kainan University (grant number: No.10509). The school provided the fully supports and had no any involvements toward this study.

Ju-yin Yang, E.d.D., Assistant Professor, Department of Applied English, Kainan University.
} 
and "stimulate learners learning pursuit" (Kong \& Song, 2015, p. 228; Njenga \& Fourie, 2010).

Besides, the educators in educational fields are seeking the ways of improving college students' learning performance, not only in their domain knowledge but also their language competency. According to the EF English Proficiency Index (EF EPI, 2014), it ranks globally 63 countries English proficiency for adult learners, Taiwan is ranked as number 30, moderate proficiency in the world and listed as number seven out of fourteen in Asia. Taiwan is 52.56 which left beyond Malaysia (59.72), Singapore (59.58), South Korea (53.62), India (53.54), Japan (52.88) and Indonesia (52.74). This is also discussed by ETS (2012) compared the TOEIC scores with other countries, the average TOEIC scores of college students in Taiwan is 539 , it was 542 in 2011, which are lower than the students in Mainland China (747), Philippine (687), and Korea (628), even the lower score ranged from 70 to 80 than the high school students.

This is the huge problem to college students, not only for academic achievement but also for future job requirement preparation. In order to help students improve their domain knowledge and language proficiency, teacher educators seek for the effectiveness way of teaching and learning English. Current studies (Chen, Chang, \& Yen, 2012; Hwang, Wu, \& Ke, 2011; Kong \& Song, 2015; Njenga \& Fourie, 2010; Yang \& Che, 2015; Yang, Li, \& Lu, 2015; Schneckenberg, Ehlers, Adelsberger, 2011) in higher education have noted to utilize the latest technology devices, such as blending learning, online learning, mobile learning, and flipped classroom instruction (Albert \& Beatty, 2014; O’Flaherty \& Phillips, 2015), which have showed the significant improvement to provide the evident for teaching and learning more interactive and effective.

In addition, Pluta, Richards and Mutnick (2013) said the course offered for college students should emphasize on "knowledge application" or "domain knowledge" (Gebre, Saroyan, \& Bracewell, 2014). Korthagen (2010) suggested that "many teacher educators seem to forget that educational knowledge cannot be simply 'transmitted' to teachers, and thus improve their actions" (p. 99). As learners can get involvement with the knowledge specific areas while learning English with the development of Bring Your Own Device (BYOD), they are capable to take in charge of their self-learning manipulating the learning in an effective way (Atkinson, 2011; Bierstaker, Janvrin \& Lowe, 2014; Pittaway, 2012).

Therefore, for the college students especially those who major in the Applied English, their English levels of proficiency are required stronger language performance than the other majors of students (Lin, 2014). This study aims to understand the current English learning environment of implementing the Task-based approach (TBA) with Context-Aware Mobile Situated Learning (CAMSL) for improving learners' learning performance in higher education, and to identify the effective way of future mobile assisted language learning in English.

\section{Purpose of This Study}

The purpose of this paper is to understand the learning performance of integrating a TBA with CAMSL in the instruction of students at a private university. The researcher hopes to employ the TAB in a CAMSL environment to enhance the students' learning performance. According to YANG (2009) mentioned TBA is able to increase learners' understanding of domain knowledge and provide more opportunities to practice specific language. It is the hope of the researchers that by making use of the unique qualities of the TBA, the researcher is able to design course materials that both meet student domain knowledge learning and language performance using, which will then be used with students in the various departments to provide the basis for conducting of 
classroom activities that elicit naturalistic use of the target language. Since the performance of these tasks displays the characteristics of "doing while learning" and "learning while doing," learners do not merely actively participate in language learning, but more importantly expand students experience in cooperation, mutual learning and support (Chapelle, 1990; Yang, 2006).

More importantly, it is the "task" in the TBA needs to fit well with the learning needs and motivations of the learners so as to provide meaningful tasks and learning materials (Jonassen, 1995; Grabe, 2007; Skehan, 1998), and to complete the learners' real needs and the tasks for the real world. Recent researches (Chuang, 2010; Li \& Franklin, 2016; Tsai, 2010, Yang, 2008; Pang, 2011) in English teaching methodology have shown that in English for Specific Purposes (ESP) the TBA is better able to directly provide university and vocational school students strengthening and practice in language learning with the multiple technology tools assisted (Bebell \& O’Dwyer, 2010; Öman \& Sofkova, 2015). More importantly, modes of study and attitudes towards study shown by university students today are no longer focused on the teacher lecturing in front of the class while the students simply take notes (Bearne \& Wolstencroft, 2007). On entering the job market, a great many university graduates report that the English education provided at school fails to meet the demands of the job market. For this reason, educators are supposed to continue to innovate and make breakthroughs on the level of teaching methodology, adopting methodologies that focus on the learner, and of integrating mobile technologies to cultivate the skills needed by students in the world beyond school (Miller \& McVee, 2012; Kress, 2005).

In this paper, the TBA is combined with a CAMSL system to improve the professional English ability of university students. Besides providing an environment that enables multiple-modality English language learning in order to encourage more active, self-directed styles of learning, this project also aims to include a CAMSL environment that can help improve university students' professional English skills, and which enables appropriate teaching strategies that further lead greater learning effects in the students' learning efforts, and thereby reach the goal of making a seamless connection between on-campus English study and the English requirements of the international commercial world.

\section{Significance of the Study}

This study represents four reasons for making the great significance. First of all, it shows the advantages and disadvantages of using mobile devices with CAMSL in higher education. Second, it provides new information on the impact of using the task-based approach on English teaching and learning. Third, it clarifies the influence of various mobile devices of English teaching and learning and individual usage of mobile devices focus on the campus English. Last but not least, the results indicate that mobile devices with the TBA are supposed to consider the language abilities and the fields of domain knowledge that students are required to obtain in the future language learning.

\section{Literature Review}

\section{Task-based Approach in Higher Education}

Recently, many researches examining how the computer technology devices may impact the performance of language teaching and learning. However, few studies have conducted the communicative approach with mobile devices. Hence, the researcher tries to collect some relevant research papers which conducted the TBA with the computer technology devices usage, particular in college levels for discussion. The TBA has been used to 
develop language curriculum in various countries as an essential way of language teaching and learning of viewing English as Second/foreign language (EFL) in higher educational system (R. Richards, Schmidt, Platt, \& Schmidt, 2003), for instance, Chinese, Spanish, German, French, Japan, Korea, and New Zealand (East \& Benjamines, 2013). Most of the instructors who conduct TBA in teaching environment aim to provide learners' opportunity to use the specific language and experience the "real world' activities task design. It gives learners the meaningful way of learning. TBA is also viewed as a vehicle which bridges the teacher-centered to student-centered method. Teachers can be the less control and are going to act as a facilitator in the classroom management. Based on the previous studies, task has been noted in various definitions (Zhang \& Hung, 2013). According to Ellis $(2003,2006)$ definition of TBA, the task is divided into three stages: first, prettask is the establishment of prior knowledge, second, task, is performance of the task, and third, posttest, is evaluation of the completed task. Nunan $(1989,2005)$ emphasizes the task "is a piece of meaning focused work involving learners in comprehending, producing and/or interaction in the target language, and that tasks are analyzed or categorized according to their goal, input data, activities, settings and roles" (p. 11). TBA with the use of computer technology assistance has been viewed as the "effective medium” of foreign language teaching (Jiang \& Sun, 2010). Students can raise their learning motivation through involving the computer technology. Students can learn with the assistance of computer technology and provide more nature environment (Groffman, 1981; Thomas, 2015). With the designing of the TBA, each stage is described in details in Table 1.

Table 1

Task Structure in the Task-based Learning Approach

\begin{tabular}{|c|c|c|}
\hline Stage & Task & Notes \\
\hline & & Establishment of Prior Knowledge \\
\hline 1 & Pre-task & $\begin{array}{l}\text { The teacher should assist students in accessing prior knowledge relevant to the task, such as the } \\
\text { category of the task, its main point, details, skills that may be learned. }\end{array}$ \\
\hline 2 & Task & $\begin{array}{l}\text { Performance of the Task } \\
\text { In the process of performing the task, the teacher provides clear instructions and assistance. While } \\
\text { performing the task, each student should be provided with equivalent opportunities for learning } \\
\text { based on their individual levels and abilities. }\end{array}$ \\
\hline 3 & Post Task & $\begin{array}{l}\text { Evaluation } \\
\text { This section is comprised of three sub-goals: } \\
\text { 1. Provide the learner with an opportunity to repeat the practice and performance of the task. } \\
\text { 2. Encourage the learner to give feedback on how to do the job. } \\
\text { 3. Encourage the learner to pay attention to the focus language points in terms of vocabulary, } \\
\text { grammar and sentence patterns. }\end{array}$ \\
\hline
\end{tabular}

\section{Attitudes Toward Context Aware Mobile Learning System}

In higher education, the colleges and universities are developing so called "E-Campus" or "Smart campus" for BYOD for authentic learning and improving learning performance. The use of CAMSL System is viewed as the one of the popular trends in subject learning and expanding into the educational teaching and learning. In spite of many ongoing research projects concerning the use of CAMSL Systems in various teaching contexts, little research has been carried out into the integration of language instruction with CAMSL put into practice in institutions of higher education. For educational policy makers, curriculum developers, and teachers on the front lines of education, it is important to design appropriate pedagogical activities that keep in step with the development of wireless mobile technology and context aware systems, so as to provide university students with 
individualized service and unlimited learning opportunities (p. 12) and call for a numeric ability (Sinayev \& Peters, 2015).

Students don't just acquire knowledge in the classroom. They can also transform traditional paper textbooks and teacher's handwritten materials into digital format that can be used on devices such as pocket PCs, cell phones and tablet computers that can be carried on one's person, to bring education into the experience of the CAMSL environment. Additionally, as pointed out by Huang \& Qiu (2005), the following three principles are to be adhered to in the implementation of CAMSL or integrated technology digital learning and real life context learning strategies (Hoffman, 2014; Jackie, Karel, \& Christian, 2017). First of all, the strategy is necessary to record students' learning progress in the real life learning environment, in order to analyze the students' ability to promptly deal with real life problems, and also to determine individualized course programs and learning activities. Second, to provide complete teaching and activity for use in the integrated real life and digital learning environment to assist teachers and students in fully utilizing the possibilities afforded by the digital learning environment to increase student ability to test, analyze and solve problems, as well as to foster peer cooperation. Third, to provide support and assistance to students in the real life learning environment through the use of online discussion groups to conduct classroom discussion and respond to students' questions.

When there is nobody to answer the questions, it becomes necessary to use information technology to establish a way to solve problems in the discussion area or a mechanism for providing correct explanatory information, as well as to document the progress of students' discussing and solving problems in the real life environment.

\section{Research Methodology}

This research method is involved the Convergent Parallel Design by Creswell (2003) mixed research framework, which adopts both quantitative and qualitative methods. The quantitative method is adopted to understand students' English performance, which included pretest and posttest about their language achievement All participants are asked to take the pretest at the beginning of the semester and posttest after the 16 weeks instruction; a quantitative research method is included the open ended questions about their perspective of CAMSL and the experience of using the mobile devices inside and outside the classroom. Pretest and posttests will be given during the class time and the link of online survey will email to all participants who are enrolled in this class. In addition, all participants will receive an Informed Consent Form Checklist from the researcher to make sure that they all understand this study and agree to participate in this study.

\section{Research Questions}

Based on the considerations outlined above, the goals of this research are posted the research question as follow: Is there a significant difference in the improvement of English learning by using the task-based approach with the context aware mobile situated learning for college students' learning performance?

\section{Participants}

This study conducts experimental targets are primarily students enrolled from the Department of Tourism and Hospitality Management, Department of Applied English, Department of Applied Japanese, International Honors Program (IHP), Department of Business and Department of Tourism and Hospitality Management at a 
university with a simple of 83 participants. Most of students are native speakers of Chinese, learning English as their foreign language. It makes use of the random choice method (i.e., students freely choosing the class), to select undergraduate and graduate students, with 42 of them serving as the experimental group who will be taught a class by TBA with CAMSL; the other group is control group which will be made up of remaining 41 students, who will study the same materials by non-TBA with CAMSL. The participants meet the English class once a week and three hours for a total week. Both of the groups will use the same textbooks, same materials, but receiving different teaching approaches.

\section{Instruments}

The data collection for this study is mainly gathered by three ways: (a) PVQC Hospitality \& Tourism Expert Examination, (b) Online survey, and (c) Informed Consent Form. The detailed are listed below:

(a) PVQC Hospitality \& Tourism Expert Examination: the researcher uses PVQC which is designed by the National Taiwan Normal University and Global Learning and Assessment Development in Taiwan. It conducted with the high validity and reliability toward the test design. Nowadays, many universities viewed this certificate as a credential graduate requirement for college students. The researcher retrieved the test materials from the following website:

(https://sites.google.com/site/2015gladworldhouse/software)

(b) Online survey via email: the online survey is generated using Survey Monkey software to capture participants' background information, such as gender, age, the Learning experience, the years of using technology tools and express their perspectives toward the TBA with CAMSL-Learning groups and non-TBA with CAMSL. The format of the survey questions included the 5 multiple-choice items, 2 items for fill in blank, and 10 open-ended questions. Students are required to express their ideas and suggestions by answering these 17 questions.

(c) Informed Consent Form

This informed consent form gives every participant the clear ideas toward this study and receives the agreement to join this study voluntarily. The researcher will respond to participants' questions and provide more information when they need. Most of participants are non-native speakers. The researcher can translate the meaning of questions.

\section{Face Validity for Online Survey}

In order to improve the content of the online survey questions, the researcher invited three professors who hold the Ph.D. degree of Teaching English to Speakers of Other Languages and Business Administration; also ask eleven students to check the questions. All professors and students are asked to give feedback after reviewing all questions.

\section{Materials Design}

The content of the CAMSL is selected as the main mobile device system for this study. There are five tasks which are focused on the Tourism and Hospitality Management related areas, such as make plan, check in, make a reservation, dinning in a restaurant, and dealing with problems. Figure 1 shows the hot spot points which students can; Figure 2 shows the one of screen capture about New York Lounge; Figure 3 shows the ESP English platform. 


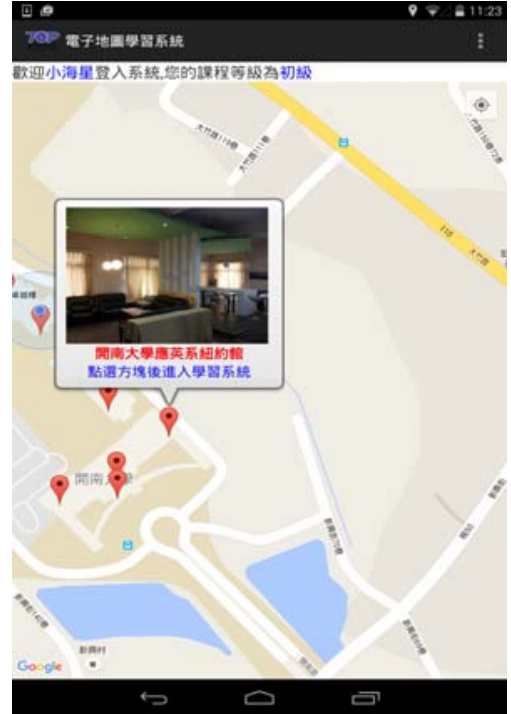

Figure 1. Hot Spot Points.

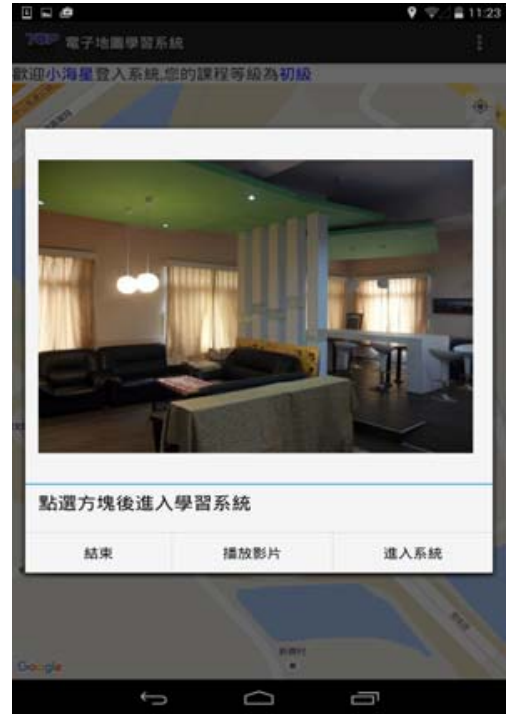

Figure 2. Screen Capture.

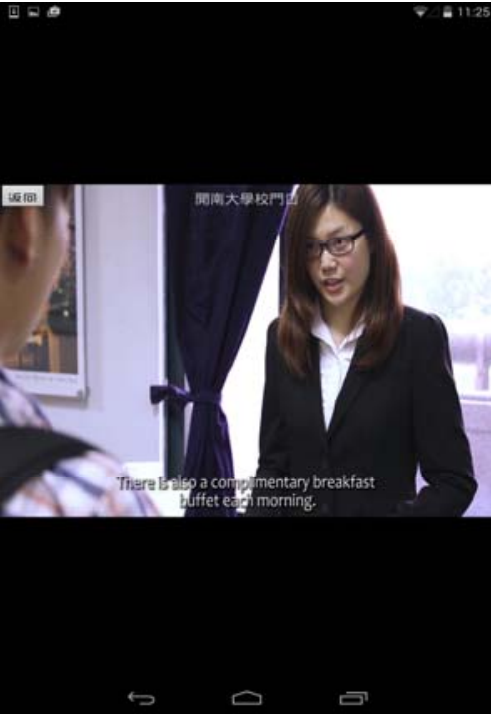

Figure 3. ESP English Platform.

\section{Data Collection}

This is a one year experimental research. The gathering of data will proceed in two stages. The first stage will include the creation of teaching materials for both CAMSL modes. Tasks include the creation of digital teaching materials, mobile interface design, on-site filming of real learning environment, and the design of student learning documentation. The second stage is the use of the mobile situated system for research on students' learning performance. The researcher examines the learning performance of examinees by means of a pre- and post-test administered to both CAMSL-Learning groups with task based approach and CAMSL-Learning groups with non-task based approach. Additionally, the researcher will ask students to do the online survey system via email for the both groups. The online survey via email will participate in two 30-minute individually, the first before class and the second will be the end of the semester. Through these online surveys, the researcher hopes to better understand the student's opportunities and ways of using Context-Aware learning. The researcher is also interested in hearing other thoughts and suggestions from the students.

\section{Smart Campus Environment}

This researcher has chosen a private university located in Taoyuan City, Taiwan based on its Smart Learning Environment. On July 18, 2012, it was licensed as a Near Field Communication , Trusted Service Management (NFC, TSM) system, leading the field with it NFC City Application System. Following upon the spread of NFC smart phone applications and also the promotion of various NFC applications, this university announced a number of all-direction NFC operation global services, including NFC smart phone, Kfone, NFC safety components (NFC SWP SIM, NFC SWP SD card), and general smart phone NFC safety components (NFC SDcard, iPhone, icaisse). This university has worked in tandem with members of the industry to promote NFC "Smart City" application services, of which the transportation and tourism NFC application service is the most outstanding (source: Kainan University Mobile Business Development Operations Center).

\section{Data Analysis}

In order to examine the improvement of learning English with CAMSL-Learning with task based approach 
and CAMSL-Learning groups with non-task based approach. The researcher applies the comparing results scores of PVQC Hospitality \& Tourism Expert examination with the assistance of SPSS software to examine their learning achievement. There are a number of statistical programs for analyzing data, such as mean scores, standard deviation, and Paired sample t test. The t-test is used to examine the students' learning performance between the control and experimental groups. For the reliability of the content analysis, the researcher invites three experts to assess students' online response. In order to gain the correct understanding from the students, experts use the rubric to check students response and the quality of the online statement. The results of experts suggestions will be given which represent the adequate reliability.

\section{Results}

\section{Result of Pretest Score From PVQC Hospitality \& Tourism Expert Examination}

From the result, $\mathrm{t}=-.403, \mathrm{P}>.05$ (Sig. $=.688$ ) the data showed no significant which means there is no significant in their ability of Hospitality \& Tourism English performance between the experimental group and control group before the treatment (see Table 2).

Table 2

Result of Pretest Score Between the Experimental Group and Control Group

\begin{tabular}{lllll}
\hline & Mean & $\mathrm{t}$ & $\mathrm{df}$ & Sig.(2-tailed) \\
Pretest (Before-After) & -.06024 & -.403 & 82 & .688 \\
\hline
\end{tabular}

\section{Result of Posttest Score From PVQC Hospitality \& Tourism Expert Examination}

From the result, $\mathrm{t}=-.4326, \mathrm{P}<.05$ (Sig. $=.000$ ) the data showed significant which means there is significant difference in their ability of Hospitality \& Tourism English performance between the experimental group and control group after the treatment (see Table 3).

Table 3

Result of Posttest Score Between the Experimental Group and Control Group

\begin{tabular}{lllll}
\hline & Mean & $\mathrm{t}$ & $\mathrm{df}$ & Sig.(2-tailed) \\
Posttest (Before-After) & -4.44578 & -.4326 & 82 & .000 \\
\hline
\end{tabular}

\section{Conclusion}

This study examines students' learning performance whether using the task-based approach with the context aware mobile situated learning or not (is using the task-based approach with the context aware mobile situated learning improved not not?). The findings represent that using the task-based approach with the CAMSL provides the significant improvement, when compared to the control group with using the task-based approach with non-context aware mobile situated learning. The CAMSL system might be more appealing on using the CAMSL to catch learners' attention, increase learning motivation, and develop their self-learning ability. In addition, CAMSL is an interesting device for college students to learn the domain knowledge, understand how to use the vocabulary in the suitable situation, gain the interesting experience in learning, offer more interactive learning atmosphere, and the most important thing is using the self-mobile devices to create free learning opportunity for students on campus. Some limitations with the respect to the English learning performance, 
language, particular English, is the hardest subject for Tourism and Hospitality Management students. Students need the extra helps than other majors students. Taken together, they often assumed that Tourism and Hospitality Management students are not interested in learning English, because they may not have chance to use it or their English ability is not good enough to deal with the all English situation. During this experiment, Tourism and Hospitality Management students just need the ways to guide them and show them how to use the suitable way to learn English. They did the improvement after this treatment. For the further research into this point, perfectly, the content design for students, the appropriate machine to get involve, the teaching methodology to use and the way of testing students should have a more constant implementation. With having these consideration, the further research could be achieved the effective English learning for these various purposes.

\section{References}

Albert, M., \& Beatty, B. (2014). Flipping the classroom applications to curriculum redesign for an introduction to management course: Impact on grades. Journal of Education for Business, 89, 419-424.

Antonio, A., \& Tuffley, D. (2015). First year university student engagement using digital curation and career goal setting. Research in Learning Technology, 23, 1-14.

Atkinson, K. (2011). Alternative approaches to second language acquisition. New York: Routledge.

Bearne, E., \& Wolstencroft, H. (2007). Visual approaches to teaching writing: Multimodal literacy 5-11. London: Sage.

Bebell, D., \& O’Dwyer, L. M. (2010). Educational outcomes and research from 1:1 computing settings. The Journal of Technology, Learning, and Assessment, 9(1), 5-15.

Bierstaker, J., Janvrin, D., \& Lowe, D. J. (2014). What factors influence auditors' use of computer-assisted audit techniques? Advance in Accounting, 30(1), 67-74.

Chapelle, C. A. (1990). The discourse of computer-assisted language learning: Toward a context for descriptive research. TESOL Quarterly, 24, 199-225.

Chen, I. J., Chang, C. C., \& Yen, J. C. (2012). Effects of presentation mode on mobile language learning: a performance efficiency perspective. Australasian Journal of Educational Technology, 28(1), 122-137.

Chuang, Y. Y. (2010). Task-based language approach to teach EFL speaking. Journal of National Huwei University of Science \& Technology, 29(4), 37-52.

East, M., \& Benjamins, J. (2013). Task-based language teaching from the teachers' perspective. Language \& Intercultural Communication, 13(3), 363-366.

EF, Education English Proficiency Index, the World's Largest Ranking of English Skill, Retrieved August 6, 2015 from: http://www.ef.co.uk/epi/spotlights/asia/

Ellis, R. (2003). Task-based language learning and teaching. New York: Oxford University Press.

Ellis, R. (2006). Current issues in the teaching of grammar: An SLA perspective. TESOL Quarterly, 40(1), 83-107.

ETS (2012). TOEIC, Test of English for International Communication, Research Papers for comparing Japan, Korea, and Taiwan employees’ English Proficiency, Retrieved July 6, 2015 from: http://www.toeic.com.tw/report_2012_01_03.jsp

Gebre, E., Saroyan, A., \& Bracewell, R. (2014). Students' engagement in technology rich classrooms and its relationship to professors' conceptions of effective teaching. British Journal of Educational Technology, 45(1), 83-96.

Grabe, M., \& Grabe. C. (2007). Integrating technology for meaningful learning (5th ed.). New York: Houghton Mifflin Company. Goffman, E. (1981). Forms of talk. Philadelphia: University of Pennsylvania Press.

Hoffman, R. R. (2014). The psychology of expertise: Cognitive research and empirical AI. New York, NY: Psychology Press.

Hwang, G. J., Wu, P. H., \& Ke, H. R. (2011). An interactive concept map approach to supporting mobile learning activities for natural science courses. Computers \& Education, 57(4), 2272-2280.

Jackie, M. P., Karel, V. D. B. D., \& Christian, P. J. D. (2017). Battling bias: Effect of training and training context. Computers \& Education, 111(4), 0360-1315.

Jiang, L., \& Sun, K. (2010). Task-based approach in college english teaching of digital-based Context. I.J.Modern Education and Computer Science, 1, 32-39.

Jonassen, D. H. (1995). Supporting communities of learners with technology: A vision for integrating technology with learning in schools. Educational Technology, 35(4), 60-63. 
Khan, M. A., \& Khan, M. R. (2015). An ESP pre-service extensive writing course for the young Pakistanis opting for banking as a future profession. International Journal of Language and Linguistics, 2(5), 101-112.

Kong, S. C., \& Song, Y. (2015). An experience of personalized learning hub initative embedding BYOD for reflective engagement in higher education. Computers \& Education, 88, 227-240.

Korthagen, F. A. J. (2010). Situated learning theory and the pedagogy of teacher education: Towards an integrative view of teacher behavior and teacher learning. Teaching and Teacher Education, 26, 98-106.

Kress, G. (2005). Gains and losses: New forms of texts, knowledge, and learning. Computers and Composition, 22(1), 5-22.

Leroux, J. A., \& Lafleur, S. (1995). Employability skills: the demands of the workplace. The Vocational Aspect of Education, 47(2), 189-196, DOI: 10.1080/0305787950470207

Li, K., Li, Y., \& Franklin, T. (2016). Preservice teachers' intention to adopt technology in their future classrooms. Journal of Educational Computing Research, 54(7), 946-966.

Lin, L. F. (2017). The integration of the problem-based learning approach into a web-based English reading class. Journal of Educational Computing Research, Retrieved May 20, 2017, DOI: https://doi.org/10.1177/0735633117705960

Lin, M. S. (2014). The difficulties and future-Lead to the great future. Global education association in Taiwan. Retrieved December 6, 2015 from: http://www.geat.org.tw/?p=5729

Miller, S. M., \& McVee, M. B. (Eds.). (2012). Multimodal composing in classrooms: Learning and teaching for the digital world. New York: Routledge, Taylor \& Francis Group.

Njenga, J. K., \& Fourie, I. C. H. (2010). The myths about e-learning in higher education. British Journal of Educational Technology, 41(2), 199-212.

Nunan, D. (1989). Designing tasks for the communicative classroom. Cambridge: Cambridge University Press.

Nunan, D. (2005). Important tasks of English educators: Asian-wide and beyond. Asian EFL Journal, 7(3), 21-34.

O’Flaherty, J., \& Phillips, C. (2015). The use of flipped classrooms in higher education: A scope review. Internet and Higher Education, 25, 85-95.

Öman, A., Sofkova Hashemi, S. (2015). Design and redesign of a multimodal classroom task-Implications for teaching and learning. Journal of Information Technology Education: Research, 14, 139-159. Retrieved from http://www.jite.org/documents/Vol14/JITEv14ResearchP139-159Oman0743.pdf

Pang, M. M. (2011). Perspectives of using the task-based approach on hospitality management college students (Unpublished master dissertation. Kainan University, Taiwan).

Pluta, W., Richards, B., \& Mutnick, A. (2013). PBL and beyond: Trends in collaborative learning. Teaching and Learning in Medicine, 25(S1), S9-S16.

Richards, J., Schmidt, R., Platt, H., \& Schmidt, M. (2003). Longman dictionary of applied linguistics. London: Longman.

Schneckenberg, D., Ehlers, U., \& Adelsberger, H. (2011). Web 2.0 and competence-oriented design of learning-potentials and implications for higher education. British Journal of Educational Technology, 42(5), 747-762.

Sinayev, A., Peters, E. (2015). Cognitive reflection vs. Calculation in decision making. Frontiers in Psychology, 6, 532.

Skehan, P. (1998). A cognitive approach to language learning. Oxford: Oxford University Press.

Pittaway, S. M. (2012). Student and staff engagement: Developing an engagement framework in a faculty of education. Australian Journal of Teacher Education, 37(4). http://dx.doi.org/10.14221/ajte.2012v37n4.8

Tsai, S. C. (2010). Developing and integrating courseware for oral presentations into ESP learning contexts. Computers \& Education, 55, 1245-1258.

Thomas, M. (2015). Contemporary task-based language teaching in Asia. Publisher's city name: Bloomsbury Academic, U.S.A.

Yang, J. Y.(2009). Integrating the task-based approach and the grammar translation method with computer-assisted instruction on Taiwanese EFL college students’ speaking performance. Taipei: Bookman.

Yang, J. Y., \& Che, P. C. (2015). Improving college students’ English learning with Dr. Eye Android MID. The Turkish Online Journal of Educational Technology, 14(2), 101-109.

Yang, S. J. H. (2006). Context aware ubiquitous learning environment for peer to peer collaborative learning. Educational Technology \& Society, 9(1), 188-201.

Yang, X., \& Li, X., \& Lu, T. (2015). Using mobile phones in college classroom settings: Effects of presentation mode and interest on concentration and achievement. Computers \& Education, 88, 292-302.

Zhang, X., \& Hung, S. C. (2013). A case study of exploring viability of task-based instruction on college english teaching in big-sized class. Journal of Language Teaching and Research, 4(4), 693-699. 